\title{
Understanding small rhenium molecules kinetically and structurally in a macromolecular setting
}

\author{
Francois (FJF) Jacobs and Alice Brink \\ Department of Chemistry, University of the Free State, Bloemfontein 9301, South Africa. \\ fjjjacobs7@gmail.com
}

Since the development of the ${ }^{99 \mathrm{~m}} \mathrm{Tc}$ generator in the 1950 's and subsequent introduction of the ${ }^{188} \mathrm{Re}$ generator the development of technetium and rhenium radiopharmaceuticals has been of great interest to the scientific community. ${ }^{1}$ Our research is focused on the development of a target specific radiopharmaceutical. [2] In particular we are interested in using chemical functionalities of biological significance as targeting vectors for model radiopharmaceuticals wherein potential theranostic applications are considered using both ${ }^{99 \mathrm{~m}} \mathrm{Tc}$ and ${ }^{188} \mathrm{Re}$ nuclides in a cluster complex. [3]

This study is focused on the $f a c-\left[\operatorname{Re}(\mathrm{CO})_{3}\right]^{+}$moiety [4-6] and utilizes the $\{2+1\}$ mixed ligand concept, [7] which gives the freedom to coordinate a bioactive site-containing molecule as either a monodentate or bidentate ligand to the $f a c-\left[\operatorname{Re}(\mathrm{CO})_{3}\right]^{+}$core. Model complexes were synthesised, aimed at improving the linking between a biomolecule and the metal centre. Additionally, investigations into altering the nuclearity of metal complexes for the development of theranostic radiopharmaceuticals will be discussed. In order to understand the possible pathways that a particular drug may partake in during administration, kinetic investigations were considered important. [8] For this reason we have conducted substitution kinetics to further our understanding on how these metal complexes could behave in vivo. Furthermore, we will focus on exploring the weak interactions such as hydrogen bonding as observed in small molecule crystal structures and coordinate to a protein residue in an attempt to understand and predict how and where these compounds will interact in a biological setting.

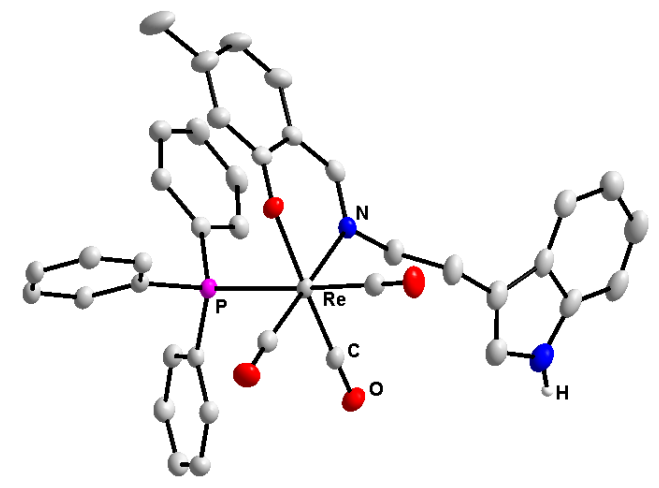

Figure 1. Crystal structure of the kinetic substituted complex $f a c-\left[\operatorname{Re}(\mathrm{CO})_{3}(5-\mathrm{Me}-\mathrm{SalH}-\mathrm{Tryptamine})\left(\mathrm{PPh}_{3}\right)\right]$ containing the tryptamine moiety.

[1] Jürgens, S.; Herrmann, W. A.; Kühn, F. E. (2014) J. Organomet. Chem. 751, 83-89.

[2] Top, S.; Hafa, H. El; Vessières, A.; Jaouen, G.; Quivy, J.; Vaissermann, J.; Hughes, D. W.; McGlinchey, M. J.; Mornon, J. P.; Thoreau, E. (1995) J. Am. Chem. Soc. 117, 8372-8380.

[3] Mokolokolo, P. P.; Frei, A.; Tsosane, M. S.; Kama, D. V; Schutte-smith, M.; Brink, A.; Visser, H. G.; Meola, G.; Alberto, R.; Roodt, A. (2018) Inorganica Chim. Acta 471, 249-256.

[4] Alberto, R.; Schibli, R.; Schubiger, P. A. (1996) Polyhedron 15, 1079-1089.

[5] Jacobs, F. J. F.; Brink, A. (2020) Zeitschrift für Krist. - New Cryst. Struct. 236, 253-255.

[6] Jacobs, F. J. F. FUNCTIONALISED NITROGEN BASED LIGANDS IN DINUCLEAR RHENIUM MODEL RADIOPHARMACEUTICALS, Univeristy of the Free State, 2020. (Supervisors Brink, A. \& Venter, G.J.S.)

[7] Mundwiler, S.; Kundig, M.; Ortner, K.; Alberto, R. (2004) Dalton Trans. 99, 1320-1328.

[8] Tonge, P. J. (2018) ACS Chem. Neurosci. 9, 29-39.

Keywords: Rhenium radiopharmaceutical, N,O-Bidentate ligand, Substitution kinetics, Crystallography, Protein coordination Acta Cryst. (2021), A77, C724 